\title{
Relation of uranium to hypogene mineral zoning in the Front Range mineral belt, Colorado
}

By S. R. Wallace, B. F. Leonard, and R. H. Campbell

\section{Trace Elements Investigations Report 357}

UNITED STATES DEPARTMENT OF THE INTERIOR GEOLOGICAL SURVEY 
Geology and Mineralogy

This document consists of 43 pages, plus 2 figures.

Series A

UNITED STATES DEPARTMENT OF THE INTERIOR

GEOLOGICAL SURVEY

\section{RELATION OF URANIUM TO HYPOGENE MINERAL ZONING \\ IN THE FRONT RANGE MINERAL BELT, COLORADO}

By

S, R. Wallace, B. F. Leonard and R, H, Campbell

August 1955

Trace Elements Investigations Raport 357

This preliminary report is distributed without editorial and technical review for conformity with official standards and nomenclature. It is not for public inspection or quotation,

This report concerns work done on behalf of the Division of Raw Materials of the U. S. Atomic Energy Commission. 
Distribution (Series A)

No. of copies

Argonne National Laboratory

A tomic Energy Commission, Washington

Division of Raw Materials, Albuquerque.

Division of Raw Materials, Butte

Division of Raw Materials, Casper

Division of Raw Materials, Denver .

Division of Raw Materials, Hot Springs

Division of Raw Materials, Ishpeming

Division of Raw Materials, Phoenix .

Division of Raw Materials, St. George

Division of Raw Materials, Salt Lake City

Division of Raw Materials, Washington

Exploration Division, Grand Junction Operations Office

Grand Junction Operations Office.

Technical Information Service, Oak Ridge .

Ü. S. Geological Survey:

Fuels Branch, Washington . . . . . . . . . . . . . . . . . . . . 1

Geochemistry and Petrology Branch, Washington . . . . . . . . . . . 1

Geophysics Branch, Washington . . . . . . . . . . . . . . . . 1

Mineral Classification Branch, Washington . . . . . . . . . . . . . . . 1

Mineral Deposits Branch, Washington . . . . . . . . . . . . . 2

E. H. Bailey. Menlo Park. . . . . . . . . . . . . . . . . 1

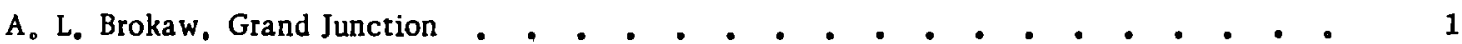

N. M. Denson, Denver . . . . . • . . . . . . • • . . . . . . 1

R. L. Griggs, Albuquerque . . . . . . . . . . . . . . . . . 1

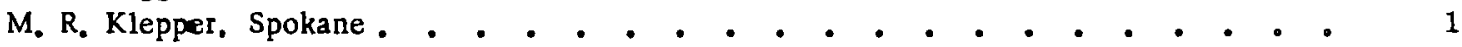

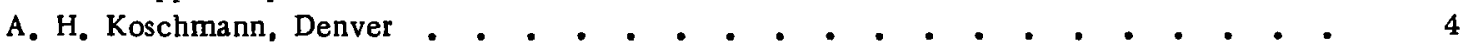

J. D. Love, Laramie . • • • • • • . • • • • • • • . . 11

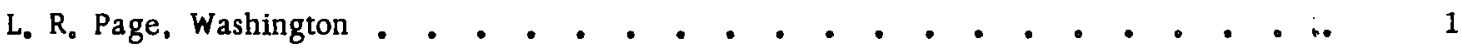

Q. D. Singewald, Beltsville . . . . . . . . . . . . • . . 1

A. E. Weissenborn, Spokane . . • • . . . . . . . . . . . . . 1

TEPCO, Denver . . . . . . . . . . . . . . . . . . . . 2

TEPCO, RPS, Washington, (including master) . . . • • • • . • • . $\frac{2}{46}$ 


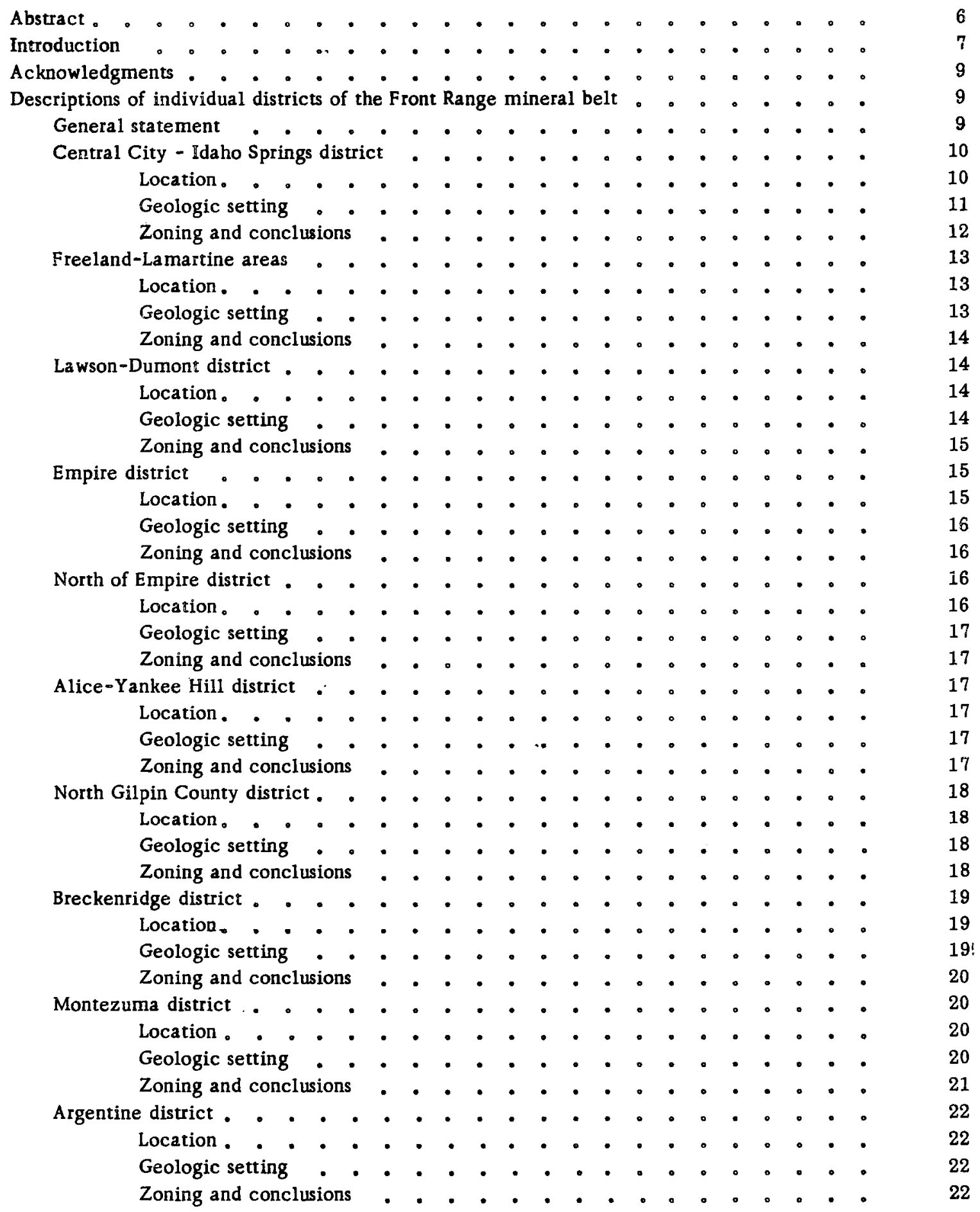


Page

Descriptions of individual districts of the Front Range mineral belt-Cost. Georgetown-Silver Plume district

\section{Location . . . . .}

Caribou district

Zoning and conclusions . . . . . . . . . . . . . . . . . 23

$0,0,0,0$

Geologic setting - . . . . . . . . . • . . . . . . . 24

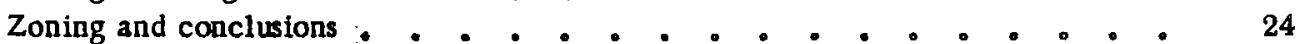

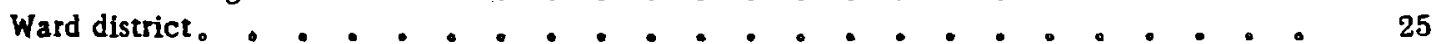

Location . . . . . . . . - . . . . . . . . . . 0225

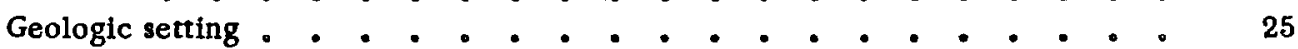

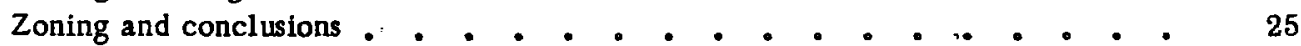

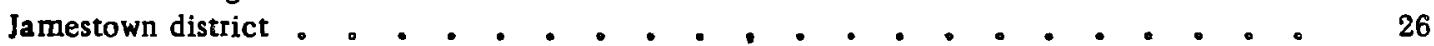

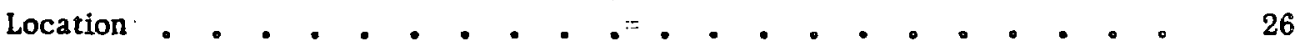

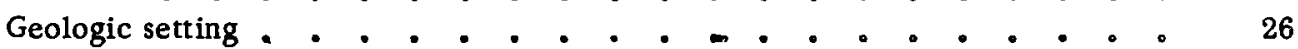

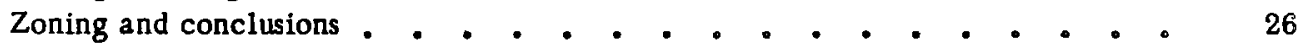

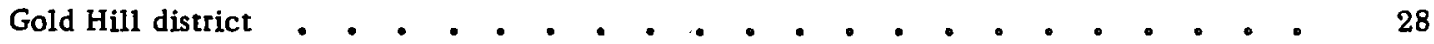

Location • • • • • • • • • • • • • • • • • • •

Geologic setting . . . . . . . . . . . . . . . . . . . 28

Zoning and conclusions . . . . . . . . . • . . . . . . . 28

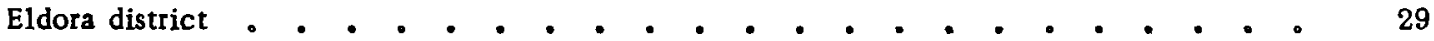

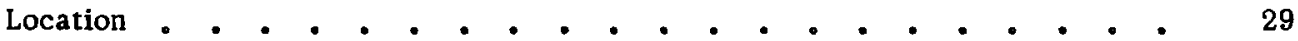

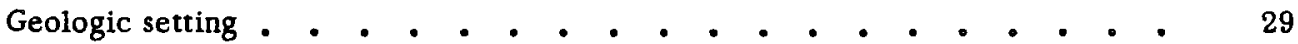

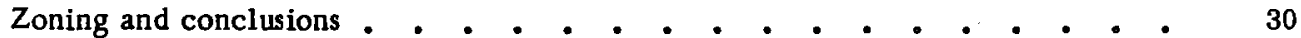

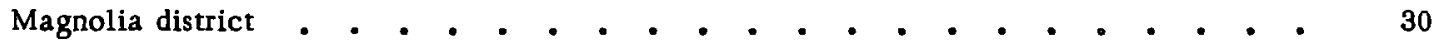

Location . . . . . . . . . . . . . . . . . . . . . 30

Geologic setting . . . . . . . . . . . . . . . . . . . 30

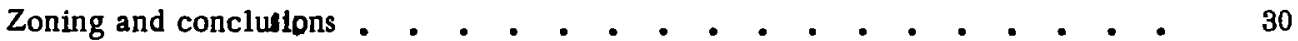

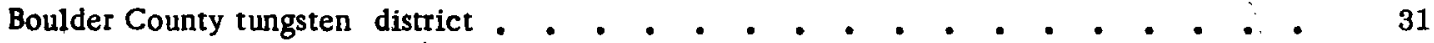

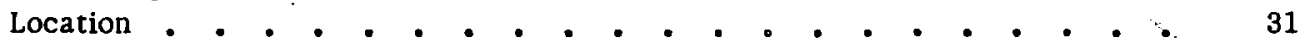

Geologic setting . • • • • • • • • • • • • • • • • . . • 31

Zoning and conclusions . . . . . . . . . . . . . . . . . 431

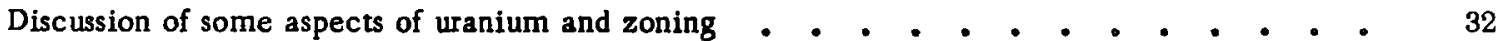

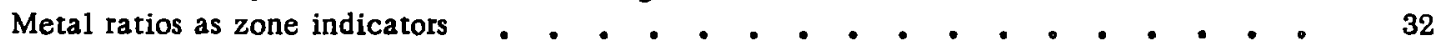

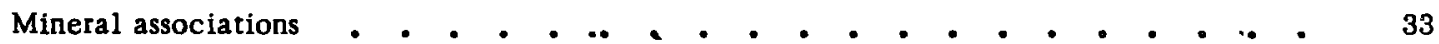

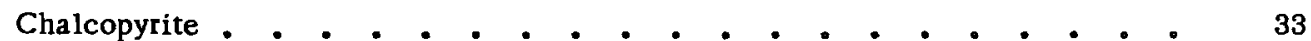

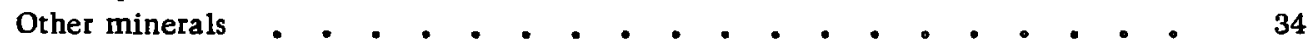

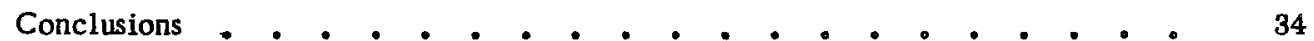

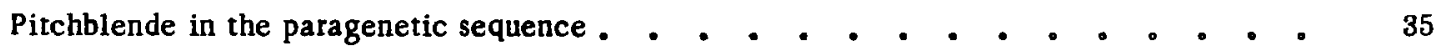

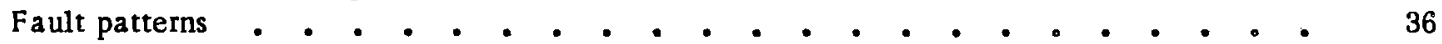

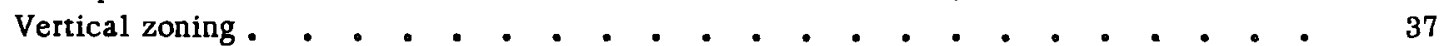

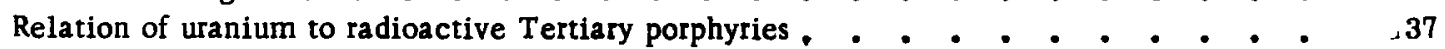

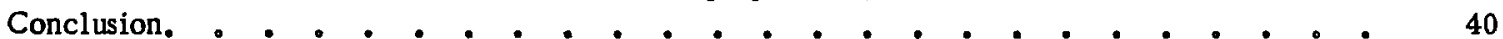

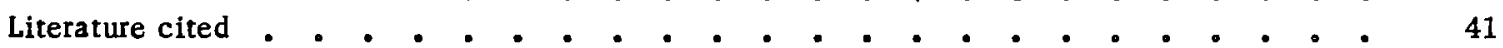




\section{ILLUSTRATIONS}

Page

Figure 1. Map of Front Range mineral belt, Colorado, showing zoning of mineral deposits and areas inferred to be favorable for pitchblende . . . . . . . . . In envelope

2. Map showing zonal distribution of metal ratios and results of radioactivity reconnaissance in the southern part of the Wallapai mining district. Mohave County, Arizona a . . . .

3. Diagrammatic sketch showing how a roughly concentric zonal pattern may be developed as a result of adjacent, en echelon cymoid vein zones . . . 


\section{RELATION OF URANIUM TO HYPOGENE MINERAL ZONING \\ IN THE FRONT RANGE MINERAL BELT, COLORADO}

By S. R. Wallace, B. F. Leonard and R, H. Campbell

\section{A BSTRACT}

Many of the mining districts of the Colorado Front Range mineral belt contain mesothermal sulfide ores that exhibit a zonal distribution. Present data indicate that in most of the zoned districts pitchblende and/or secondary uranium minerals are most abundant in a transition zone between central areas containing predominantly pyritic gold ores and peripheral areas containing dominantly lead-zinc-silver deposits. Copper in the form of chalcopyrite is also probably more abundant in the transition zone than in adjacent zones.

Many mineralized areas in the Front Range mineral belt are roughly co-extensive with and probably related to groups of Tertiary intrusives. The solutions that deposited sulfide and pitchblende in these areas probably were derived from many different types of source magma, but some bostonite magmas were probably particularly important sources of uranium-bearing solutions.

At most localities where the relative ages of pitchblende and associated sulfides are known. the pitchblende is early in the paragenetic sequence, and not of intermediate age as suggested by its zonal position. This discrepancy may be the result of overlapping zones of deposition related to adjacent centers of mineralization, to changing environments of deposition within zones during the period of mineralization, or to unknown factors.

Uranium is also present in districts in which the dominant mineralization is markedly different from the common pyritic gold-base metal sulfide mineralization. In the Jamestown district uranium appears to be associated mainly with fluorspar; in other districts that exhibit little or no systematic hypogene zoning it is ubiquitous. If uranium is present in zoned districts, a large proportion of the deposits probably should be in the transition zones. The application of this concept may be a valuable guide in prospecting for uranium. 


\section{INTRODUCTION}

Most of the Front Range mining districts exhibit a zonal distribution of metals in plan, and in mariy of these districts uranium occupies a preferred position in the zoning sequence. These relationships are most apparent in the Central City district where the application of the concept of hypogene zoning to the search for uranium was first undertaken (Leonard, 1952a; 1952b; and Leonard in King, Leonard, Moore and Pierson, 1953). The abnormally radioactive vein deposits known in 1951 are most abundant irl a transition zone between a central zone of pyritic gold veins and a peripheral zone of lead-zinc-silver veins.

This zonal distribution of uranium minerals probably exists in many other zoned metalliferous districts in the western states, at Cornwall, England, and in the Erzgebirge. The data are scarit, however, for most of these districts, and emphasis in this report is on the Front Range deposits.

The concept of a preferred position of uranium in a zonal arrangement of metals is not new. Emmons in 1926 (p. 35, fig. 4) included uranium in a generalized sequence for the deposition of metals: iron. tin. tungsten, arsenic, bismuth, gold, copper, uranium, nickel, cobalt, manganese, zinc, lead, vanadium, silver, antimony, and mercury. Uranlum, however, was incidental to Emmons ${ }^{\circ}$ presentation of the zoning hypothesis. R. U. King and F. B. Moore (oral communication, 1954) had recognized a spatial relationship of pitchblende and different types of sulfide deposits in the Quartz Hill section of the Central City district about 1950, and F. C. Armstrong (written communication) during a detailed study of Quartz Hill in 1951. independently developed Ideas on the relation of uranium to zoning in the Central City district similar to those presented in this report.

A zoning of the ores of the Central City district, based on the average silver-gold ratios from 228 veins. was first recognized by Collins (1903). Since that time the geographic distribution of vein types has been successively presented by Bastin and Hill (1917, p. 115-116, pls, 4 and 7)。 Goddard (1947. pi. 14) and Lovering and Goddard (1950, p, 170, 177, and $\mathrm{pl}, 9)$. These studies provided the framework for the present investigation of the relation of uranium to mineral zoning at Central Cíty.

The location and zonal pattem of the Idaho Springs-Central City district and of other districts showing similar mesothermal mineralization are shown on figure 1. The districts include Breckentidge, Montezuma, Freelant-Lamartine. Georgetown-Silverplume Lawson-Dumont, Empire, Alice-Yankee Hill. 
North Gilpin County. Caribou, and Ward. Also shown on.figure 1 is a zonal pattern for the Jamestown district in which the dominant mineralization is distinctly different from that of the Central City district. The Argentine, North of Empire, Eldora, Gold Hill, Magnolia, and the Boulder County tungsten districts exhibit little or no recqgnizable zoning based on available data.

The classification of different vein types which outlines the zones is based both upon mineralogy and upon records of the commodity produced. This information was obtained from many different sources and the data presented on figure 1 and the discussions of the individual districts are limited by two factors: (1) incompleteness of data--available data are scant for many mining districts within the Front Range; and (2) accuracy of data--in those districts where detailed work has been done in recent years, the results do not always agree with those of earlier studies, yet information drawn either directly or indirectly from the earlier references on the Front Range districts is all that is available for many areas.

Superimposed on the zonal patterns (fig, 1) are localities showing abnormal radioactivity. These are subdivided as follows: (1) localities with material containing 0.1 percent or more eU, and (2) localities with material containing from 0,02 to 0,09 percent eU or estimated to contain 0,02 percent or more eU on the basis of field measurement. The significance of these data is limited by variations in sampling procedure (bulk samples versus selected samples) :and by the completeness of radioactive reconnaissance coverage; in some districts no systematic reconnaissance for radioactivity has been made.

The radioactive materials indicated on the map do not include abnormally radioactive bostonites and pegmatites, or localities where radon is a principal source of radioactivity. Also omitted from the map are many localities where vein material has anomalous radioactivity ranging from $0.05 \mathrm{to} 0.3 \mathrm{mr} / \mathrm{hr}$ (milliroentgens per howr). These values are roughly two to ten times background radiation and probably few of these are equal to 0.02 percent $e U$.

The zones shown of figure 1 are empirically derived; the cause for the spatial arrangement of the deposits is not discussed, nor is this paper intended as a contribution to the solution of the general problem of mineral zoning. At present there seems to be no satisfactory answer to the question, "How and why is uranium concentrated in veins of certain zones". In many of the districts little is known concerning the source 
of mineralizing solutions, the structures which controlled their migration, and the conditions of precipitation of metals from these solutions. Such factors as contradictory evidence exhibited by the position of pitchblende in the paragenetic sequence and its position in the zonal pattern, different ages of pitchblende, successive phases of metallization, the effect of overlapping zones associated with adjacent centers, and the role of radioactive Tertiary igneous rocks, particularly bostonites, and their source magmas all need further explanation before the reasons for the distribution of uranium in the Front Range mineral belt are better understood.

In spite of the writers' inability to explain satisfactorily many of these ramifications of the problem of mineral zoning, the coincidence of uranium with the transition zones seems to be real, and the concept of zoning as applied to uranium may be a valuable clue in prospecting for uranium deposits not only in the Front Range mineral belt but elsewhere as well. It should be noted that the presence of a transition or favorable zone does not in itself predict the occurrence of uranium; it merely indicates that if uranium is present in a district, it should be more abundant within these zones.

This report is largely an interpretation of data drawn from reports by other geologists; much of the information on the Gold Hill district is based on a reconnaissance for radioactivity by Campbell and Schafer in April 1953 and on five weeks field work by Wallace and Latb in 1954.

\section{ACKNOWLEDGMENTS}

The writers wish to acknowledge the contributions of many coileagues in stimulating discussions of the problem of uranium in relation to zoning. This report is based on work done by the U. S. Geologica1 Survey on behalf of the Division of Raw Materials of the U. S. Atomic Energy Commission.

DESCRIPTIONS OF INDIVIDUAL DISTRICTS OF THE FRONT RANGE MINERAL BELT

\section{General statement}

Precambrian granite, schist, and gneiss are the dominant rocks in most of the districts of the Front Range mineral belt described in this report. The oldest rocks are metasedimentary schists and grieisses of the Idaho Springs formation. This formation is overlain by hornblende schists and gneisses of the Swandyke hornblende gneiss. Younger Precambrian rocks in ascending order are: quartz monzonite gneiss and gneissic pegmatite. Boulder Creek granite and quartz monzonite. granite gneiss and gneissic aplite. quartz diorite and hornblendite, and Silver Plume granite. 
The major Precambrian structure of the Front Range is a northeasterly trending regional anticline greatly modified by smaller, generally parallel folds, and by cross folds. The most conspicuous Laramide structures in the Front Range mineral belt are persistent northwesterly faults (the breccia reefs) that opened prior to and during intrusion of Tertiary igneous rocks; later east-northeast-. and northeast-trending faults formed during and after the intrusion of Tertiary porphyritic rocks. These intrusions occur as stocks, dikes. sills, and irregular bodies, and include limburgite, gabbro, diorite, andesite, granodiorite, monzonite, quartz monzonite, biotite latite, alkali syenite, bostonite, rhyolite, alaskite, and sodic granite. The vein deposits are Tertiary in age and are thought to be genetically related to these intrusive rocks.

In most of the districts, vein deposits of different types of ores show a geographic zonal distribution. and in many of these districts uranium seems to be most abundant in the same part of the zonal sequence. Certain types of bostonite magma appear to have yielded ore solutions relatively rich in uranium; however. uranium-bearing solutions were probably expelled from magmas of many different compositions.

Lovering and Goddard (1950) present the most comprehensive discussion of the Front Range mineral belt, and their report is the principal source of data for the discussion of the Front Range districts. Other principal sources for the various districts are: Breckenridge district - Ransome (1911), and Lovering (1934); Montezuma and Argentine districts - Lovering (1935); Ģorgetown-Silver Plume, Empire, and FreelandLamartine districts - Spurr, Garrey, and Ball (1908); Central City-Idaho Springs district - Spurr, Garrey, and Ball (1908), and Bastin and Hill (1917); Alice-Yankee Hill, North Gilpin County, and Caribou districts Bastin and Hill (1917); Eldora district - Lindgren (1907), and Bastin and Hill (1917); Magnolia district Wilkerson (1939a; 1939b); Boulder County tungsten belt - Lovering (1941). Tweto (1947), and Lovering and Tweto (1953); Ward district - Worcester (1921); Gold Hill district - - Lovering (1932), and Goddard (1940); and the Jamestown district - Goddard (1935; 1946).

\section{Central City - Idaho Springs district}

\section{Location}

The Central City-Idaho Springs district is about 30 miles west of Denver and includes about 25 square miles in the southern part of Gilpin County and the northeastern part of Clear Creek County. The 
principal towns are Central City, Blackhawk, and Idaho Springs. Thas part of the district referred to in this report as the Central City district is essentially the northern haif of the iazger area described above; che southern half is referred to in this report as the Idaho Springs area.

$$
\text { Geoiogic setring }
$$

Centrai City is on the axis of a northeasterly trending anticline of Precambrian age that exposes a core of granite gneiss about 2 miles wide bordered on both sides by the Idaho Springs formation. This formation predomlnates in the Idaho Springs area. but a large iregular mass of quartz monzonite gneiss and aplite is present along the northern edge of the Idaho Springs area and extends into the southeastern part of the Central City district. Dikes and small irregular stocks of Tertiary porphyries are abundant throughout the entire district. Quartz monzonite, including some sodic monzonite, predománates and occuss principally in the eastern and south central parts of the district. Dikes of bostonite and bostonite forphyry are common and are especially abundant in the western part of the district. Alsdorf (1916), Lovering and Goddard (1950), and Phair (1952) have suggested a genetic relation between the bostonites and uranium; the possible significance of these rocks in relation to pitchblende is discussed in a following section of this report.

Most of the T'ertiary dikes trend northeast, but some of the more persistent bostonite dikes strike west and northwest. The veins commonly strike east to northeast and have steep dips, generally more than 60 degrees. Near Idaho Springs the prevailing dip is to the northwest; in the Central City district the dips are steeper, and both northwest and southeast dips are common.

The most productive veins of the area commonly follow zones of minor faulting and the distribution of veins is in part dependent upon the physical nature of the rocks, The Idaho Springs formation is apparently less well suited to the development of large persistent fractures than other zocks in the district, and areas underlain by these rocks generally contain fewer veins than equal areas of the other rocis types of the district. The deposits of the Central City-Idaho Springs district have been worked primariiy for gold arid silver. Bastin and Hill (1917. Po 104-105) classified the ores of the district ỉnto four types: (1) pyritic gold ores, consisting predominantly of pyrite and gangue minerals with subordinate amounts of chalcopyrite. tennantite, and in places enargite and other metallic minerals; (2) galena-sphalerite ores, containing galena, 
sphalerite, and pyrite as the principal ore minerals, with minor chalcopyrite and in some places small amounts of other sulfides--silver is relatively more important than gold in these ores; (3) composite ores, which Bastin believed resulted from "double mineralization," first with minerals characteristic of type (1) ores and later with minerals characteristic of type (2) ores; and (4) telluride ores, bearing gold and silver tellurides, and showing more diversity in mineral character than the other ore types.

A nother type of ore, which Bastin and Hill (1917, p. 105) believe to be a sub-type of the pyrftic gold ores, is found in a small group of veins within, but onthe southeast.side-of the central area of pyritic gold veins (King, Leonard, Moore, and Pierson, 1953). Many veins in this part of the district contain enargite and fluorite although enargite is a subordinate constituent in all but a few of the veins. Fluorite is a characteristic gangue mineral of the rich telluride ores but also occurs in some of the pyritic ores commonly but not invariably in those containing enargite.

\section{Zoning and conclusions}

The telluride veins are confined to a narrow belt extending south-southwesterly across the east central part of the district from the vicinity of Blackhawk to about 1 mile south of Idaho Springs and were probably influenced by the Dory Hill fault which Lovering and Goddard (1950. p. 177) believe controlled the migration of the telluride ore solutions. The tellurdie ores are believed to be younger than the sulfide mineralization (Lovering and Goddard, 1950. p. 174) and have no apparent genetic relation to the pirchblende deposits.

The zonal pattern in the Central City district shows a central area of pyritic gold veins surrounded by a roughly concentric belt of lead-zinc-silver veins.

Other parts of the Central City-Idaho Springs district have similar distributions of types of deposits, with centers containing pyritic gold deposits, partly or wholly surrounded by areas of silver-lead deposits. These other pyritic gold "centers" are : (1) a north-trending arcuate area that includes the town of Idaho Springs near its northern end, (2) a large irregular area centering about 2 miles west-northwest of Idaho Springs, and bordered on the west by areas of galena-sphalerite veins in the Freeland-Lamartine area and Lawson-Dumont district, and (3) a small circular center about midway between Central City and the town 
of Dumont. These centers are outlined on figure 1 by the dot pattern which indicates the transition zone between the areas of pyritic gold veins and areas of galena-sphalerite deposits. Bastin and Hill (1917. p. 116) noted that in the Central City district veins containing ores of the composite type are most common in this transition zone. This zone is characterized by a mixture of vein types: (1) the pyritic gold veins which predominate in the core area, (2) the galena -sphalerite veins that predominate in the peripheral area, and (3) the composite veins (not everywhere present). Chalcopyrite may also be characteristfc of the transition zone. Chalcopyrite is common in many veins of the district but all mines known to have produced copper from chalcopyrite (with minor gray copper) are within the transttion zone.

The deposits of the Central City district known to contain uranium lie in or near this transitional zone (fig. 1), and the uranium occurrences in other parts of the Central City-Idaho Springs districtrshow a similar distribution in relation to the transitional zones related to other centers in the area (Leonard, 1952: and written communication, 1952). The distinct zoning pattern of the Central City-Idaho Springs district and the distribution of uranium within the district suggest that the transitional zone is especfally favorable for the occurrence of uranium deposits.

Freeland-Lamartine area

Location

The Freeland-Lamattine area covers about 12 square miles in the central part of Clear Creek County and includes the settlements of Freeland and Lamartine. It: is bounded on the east by the southwestern part of the Central City-Idaho Springs district, on the west by the northeastern part of the Georgetown-Silver Plume district, and on the north by the Lawson-Dumont district.

$$
\text { Geologic setting }
$$

Schist and gneiss of the Idaho Springs formation are the predominant country rocks in the northern two-thirds of the area; Boulder Creek granite underlies most of the area south of Lamartine, and irregular masses and lenses of Silver Plume granite are scattered throughout the entire area. Numerous Tertiary dikes, including bostonite, intrude the Precambrian rocks; most of the dikes strike northeasterly. Most of the veins in the area trend east to northeast. Mineralization was practically continuous from the Idaho Springs area into the Freeland-Lamartine area, and the ore is similar in many veins from both districts. 


\section{Zoning and conclusions}

A group of pyritic gold veins in the northeastern part of the area, in the vicinity of Freeland, is bordered on the south and west by an area of lead-zinc-silver deposits. Northeast of Freeland, the area of pyritic gold deposits is continuous with the pyritic gold center of the Central City-Idaho Springs district that includes the Stanley mines. In the Freeland-Lamarine area, as in the Central City-Idaho Springs district, most of the localities with significant uranium or high radioactivity lie within or close to the transition zone. (See fig. 1.)

In addition to the district-wide zoning, some of the individual veins and lode systems of the Freeland-Lamartine area exhibit a lateral zoning of ore minerals. Harrison (1953) describes several veins as long cymoid fractures, the central parts of which contain auriferous pyrite with some chalcopyrite and tetrahedrite; late fractures containing galena sphalerite, and minor amounts of pyrite, chalcopyrite and tetrahedrite, form the ends of the cymoids. Uranium may occupy a preferred zonal position in these cymoids that is analogous to its position in the district zoning. Harrison (written communication., 1952) states that \%...meagre data suggest that abnormal radioactivity along a zoned vein is more likely to occur on the inner side of the transition zone."

\section{Lawson-Dumont district}

\section{Location}

The Lawson-Dumont district occupies about 10 square miles in the north-central part of Clear Creek County. It includes the towns of Lawson and Dumont and is bounded on the east by the Central City-Idaho Springs district, on the west by the Empire district, and on the south by the Freeland-Lamartine area.

$$
\text { Geologic setting }
$$

The Idaho Springs formation occupies most of the eastern parts of the district; the western part is underlain by granite gneiss which is intruded by several irregular bodies of Silver Plume granite. Laramide dikes including bostonite trend generally west to northwest; one prominent bostonite dike. just notrh of the district, strikes northerly. Two small Laramide stocks of monzonitic porphyry are present in the northeastern part of the district. 
The velns occur in two distinct sets of fault-fissures. In the western part of the district a predominantly northeastward-trending set contains lead-silver ores; in the eastern part of the district a generally eastward-trending set contains pyritic gold veins. The ore minerals of the lead-silver veins are galena, sphalerite and pyrite with minor chalcopyrite; the gold content is generally low. The chief constitients of the pyritic gold ores are pyrite and quartz, generally with chalcopyrite, which in places is abundant.

$$
\text { Zoning and conclusions }
$$

The distribution of vein types outlines an elliptical area of pyritic gold veins centered about threequarters of a mile north of Dumont. This "center" is connected by a narrow south-southwestward belt passing through Dumont to the large irregular pyritic gold center that includes the northeast part of the FreelandLamartine area and the adjacent part of the Central City-Idaho Springs district to the east. The transition zone which surrounds this center contains most of the known concentrations of uranium and/or significant abnormal radioactivity.

Several uranium deposits have been reported in lead-zinc-silver veins in the western part of the district; these include pitchblende from the Jo Reynolds area (Harrison and Leonard, 1952) and the BellevueHudson mine, and torbernite from the Robineau claims (King. written communication). The area on figure 1 favorable for finding uranium has been extended westward to include these deposits. The available data are inadequate to relate these lead-zinc-silver deposite to any one of the three riearest pyrisic gold centers (Freeland-Dumont. Empire, and Georgetown-Silver Plume); and, therefore, it cannot be established that the western part of the Lawson-Dumont district is in a transitional zone.

\section{Empire district}

Location

The Empire mining district includes an area of about 8 square miles near the town of Empire in the north-central part of Clear Creek County. It is bordered on the south by the Georgetown-Silver Plume district, on the southeast by the Lawson-Dumont district, and on the north by the North of Empire district. 


\section{Geologic setting}

Most of the Empire district is underlain by Precambrian granite: Silver Plume granite in the south and Boulder Creek granite in the central and north part of the district. Other Precambrian rocks present are monzonite gneiss, gneiss and schist of the Idaho Springs formation, and pegmatite. Generally small Tertiary dikes of several types strike northeasterly; bostonite is the most common A large composite stock of monzonite, with some alaskite, is in the southwest corner of the district, and a small monzonite stock is exposed in the center of the district. Most of the metallfferous velns cut the Boulder Creek granite adjacent to the small monzonite stock; the fractures that surround the stock are probably the result of intrusion by the stock.

\section{Zoning and conclusions}

There is little evidence for symmetrical zoning of lead-zinc deposits about a core of pyritic gold deposits in the Empire district. The lead-zinc deposits, however, are most abundant along the south border of the district, whereas the pyritic deposits with gold, chalcopyrite, or both, are found to the north. Some evidence suggesting a partially concentric pattern is found in the 6,000 -foot-long Marshall and Russell tunnel. This tunnel bears about N. $23^{\circ} \mathrm{W}$. from Empire Station at the southeast edge of the district and cuts a nonproductive part of the district. However, two small veins intersected by the turnel near the heading contain pyrite, chalcopyrite, and gold, whereas both pyritic gold veins and galena-sphalerite veins occur nearer the portal (Bastin and Hill, 1917, p. 331).

No data were available in 1953 concerning radioactivity in this district. On the basis of zoning and the occurrence of bostonite dikes, however, future reconnaissance for radioactivity in the Front Range mineral belt should include this district.

\section{North of Empire district}

Location

The area referred to in this report as the North of Empire district includes about 2 square miles be-.. tween the Empire district on the south and the Alice-Yankee Hill district on the north. 
Geologic setting

The bedrock of the district, principally Idaho Springs formation with lesser amounts of quartz monzonite gneiss, Boulder Creek granite, and Silver Plume granite, is iargely covered by alluvium。 Several Laramide dikes in the central part of the district trend northeast and are paralleled by closely-spaced veins.

\section{Zoning and conclusions}

The veins of the district are generally non-productive and detailed descriptions are not given in the literature. Most of the veins are apparently of the pyritic gold type, and no lead-zinc-silver veins are known in the district. Accordingly, a zonal distribution of vein types cannot be demonstrated. Because of the absence of an intermediate zone and the generally weak mineralization, this district is considered unfavorable for the occurrence of pitchblende deposits.

\section{Alice-Yankee Hill district}

Location

The Alice-Yankee Hill district includes about 6 square miles adjacent to the southwestern corner of the North Gilpin County district. It is bordered on the southwest by the North of Empire district.

$$
\text { Geologic setting }
$$

The Idaho Springs formation underlies much of the district, but monzonite gneiss is abundant in the eastern and southern parts of the district, and several irregular bodies of Boulder Creek granite crop out along the western side. A few small bodies of Silver Plume granite and pegmatite are also present.

Tertiary intrusive rocks include a small stock of monzonite porphyry in the extreme southwestern part of the district and several bostonite dikes in the south, central, and eastern parts of the district.

$$
\text { Zoning and conclusions }
$$

The mineral deposits of this district are dominantly of the pyritic gold type, although about seven lead-zinc-copper deposits have been worked. The district shows a moderately distinct zoning with a belt of pyritic gold veins, partly surrounded by easterly-trending areas of galena-sphalerite-chalcopyrite veins. 
The transition zone between the areas in which the two types of veins predominate is shown of figure.1. Very little reconnaissance for radioactivity has been done in the district, but pirchblende has been reported from the Gold Anchor mine about half a mile northwest of Alice (Bird and Chase, written communication, 1953).

\section{North Gilpin County district}

\section{Location}

The North Gilpin County district comprises an area of about 35 square miles in the north-central part of Gilpin County and contains the small settlements of Apex, Perigo, Gilpin, and Tolland. It is bounded on the north by the Boulder County tungsten and Eldora districts, on the south by the Central City district. and on the southwest by the Alice-Yankee Hill district.

$$
\text { Geologic setting }
$$

The Idaho Springs formation is the most abundant rock unit, but large masses of granite gneiss. Boulder Creek granite, and pegmatite occur throughout the district. An elongate but highly irregular stock of Tertiary quartz monzonite porphyry extends about 4 miles in a north-south direction in the central part of the district. A much smaller stock of monzonite is in the north-central part of the district. Dikes, principally monzonite and quartz monzonite, are associated with these two stocks; several bostonite dikes occur in the southern part of the area.

The prominent Laramide faults of the district are: the Apex fault, which trends about $\mathrm{N}_{0} 6^{\circ} \mathrm{E}$. ; the Blackhawk fault, which trends about N. $40^{\circ} \mathrm{W}$. and is mineralized at its northwestern end just south of Perigo; and the Junction Ranch dike, or breccia reef fault, which parallels the Blackhawk fault in the northeastern part of the district. Most of the veins have a northeast trend, but some trend east or northwest. The veins are widely scattered through the area and are predominantly of the pyritic gold type; in general they are of minor economic importance. The mines in the vicinity of Gilpin and those just south of Apex have been the most productive in the district.

$$
\text { Zoning and conclusions }
$$

A zonal arrangement of the ore deposits is shown in the Michigan Hill area, in the southwest part of the district, where a small area of pyritic gold veins is surrounded by pyritic copper-zinc-lead veins in a pattern that is slightly elongate in a northeasterly direction. The remainder of the district contains predominantly pyritic gold and pyritic gold-copper deposits. 
The favorable or transition zone, shown on figure 1 . covers the area of overlap between the area containing principally pyritic gold veins and that containing principally pyatic copper-zine-lead veins。 The mineralogy of the deposits in the transition zone is slightly different from that of the ransitional veins in the Central City district in that veins containing predominant galena-sphalerite are lacking. The transition zone. however, does reflect a change in mineralogy, and galena, sphalerite and chälcopyrite, whichrare found in the transition zore in other districts, are present.

Although most of the radioactive anomalies are estimated to indicate less than $C_{v} 02$ percent $e U$ and are not plotted on figure 1, the percentage of veins that are radioactive is much greater in the transition zone than in other zones (Campbell and Schafer, writien communication, 1954). The apparent lack of economically significant uranium deposits in the North Gilpin County district may have a direct correlation with the generally weak base-metal mineralization of the district.

\section{Breckenridge district}

\section{Location}

The Breckenridge district occupies an area of about 45 square miles at the southwestern end of the Front Range mineral belt. It includes the town of Breckenridge, and is about 5 miles southwest of the Montezuma district and about 20 miles northeast of Leadville.

$$
\text { Geologic setting }
$$

The Idaho Springs formation and the Swandyke hornblende gneiss, with small amounts of injection gneiss and gneissic granite, are exposed along the eastem margin of the district. The Williams Range thrust fault, which trends northwest across the eastern part of the district, has brought Precambrian rocks in contact with Cretaceous sedimentary rocks on the west. Paleozoic rock are exposed in several areas in the western and southern parts of the district. The central part of the district is largely underlair by Tertiary igneous rocks of quartz monzonitic composition. Dikes and small stocks are abundant, but most of the intrusives occur as sills。

The rocks of the district are complexly folded and faulied, but nearly all the productive veins strike between $\mathrm{N}_{0} 40^{\circ} \mathrm{E}_{0}$ and $\mathrm{N}_{0} 80^{\circ} \mathrm{E}$. 
A wide variety of types of deposit have been exploited in the district; they include contactmetamorphic deposits, stockworks, veins, blanket ores, and placers, but most of the output has come from veins and placers.

\section{Zoning and conclusions}

The ore deposits of the Breckenridge district show a rough zonal arrangement analogous, in part. to that at Central City, but covering a much larger area. Pyritic-gold deposits predominate in the north and northeast parts of the district, and lead-zinc veins with gold and silver predominate in the southwest part of the district, a short distance east and southeast of the town of Breckenridge. The transition zone trends northwest through Breckenridge.

Vertical zoning is mentioned by Lovering and Goddard (1950. po 108), who state that veins of chiefly pyrite and sphalerite with a little galena commonly change abruptly downward into a nearly pure pyrite; in those veins that contain more abundant galena, sphalerite increases with depth.

King and Roseboom (written communication, 1953) examined more than 40 mines, dumps, and prospect pits in the district but found no significant anomalous radioactivity. The results of the radioactivity reconnaissance suggest that little or no uranium is present in the district.

\section{Montezuma district}

\section{Location}

The Montezuma district is that part of the Front Range mineral belt between the Breckenridge district, 5 miles to the southwest of Montezuma, and the Argentine district to the northeast.

$$
\text { Geologic setting }
$$

Gneisses and schists of the Idaho Springs formation predominate in the eastern half of the district and the Swandyke hornblende gneiss occupies most of the western half. Other Precambrian rocks include a few bodies of granite gneiss, Silver Plume granite, and pegmatite. Pierre shale of Cretaceous age is exposed in a fenster in the Williams Range thrust in the northeastern part of the district. 
A large stock of Tertiary porphyritic quartz monzonite extends for about 6 miles across the northern part of the district, Other intrusive rocks of Tertiary age include dikes of sodic quartz monzonite, granite. and rhyolite in the northeast part of the district, and monzonite and diorite to the southwest. The dikes are generally short. Commonly they strike east to northeast, but in the southwest part of the diswict many of the dìkes strike northwest.

Most of the productive veins of the district trend northeasterly; but several strong northwesterly faults, generally poorly mineralized, are present; a few easterly-trending veins are in the thrust plate immediately overlying the Cretaceous sediments in the southwestern part of the district. The ore deposits contain gold and silver, and sulfides and sulfo-salts of lead, silver, zinc, arseric, antimony, copper, and bismuth and their supergene alteration products.

\section{Zoning and conclusions}

Pyritic gold deposits predominate in the southwestern part of the district and lead-zinc-silver veins predominate to the east and northeast. The area of pyritic gold deposits in the Montezuma district is adjacent to the area of pyritic gold deposits in the Breckenridge district. and the combined zonal pattern of the two districts appears as two areas of lead-zinc-silver deposits partially surrounding a single large pyritic gold center (fig. 1). The pyritic gold area, however, is rather sparsely mineralized and most of the deposits that do occur are clustered in isolated groups suggesting small local centers. Data are inadequate to establish any direct genetic relation between the lead-zinc-silver veins and the pyritic gold deposits of the Montezuma district. and the transition zone is based empirically on the distribution of vein types. $\because$.

The area of lead-zinc-silver deposits in the Montezuma district has a wide lateral extent in a direction normal to the trend of the "contact" between the pyritic gold and the lead-zinc-silver zones, and many of the lead-zinc-silver veins exhibit a vertical zoning, Lovering (1935, P.61) notes that pyrite and sphalerite increase with depth in most of the lead-zinc-silver veins and in those which contain notable copper, chalcopyrite increases and gray copper decreases with depth. These data suggest that the interface between the pyritic gold zone and the lead-zinc-silver zone may have a relatively flat slope. If this is so. the transition zone may extend to the northeastward beyond the northeastern margin of the zone shown on the map. 
Relatively little reconnaissance for radioactivity has been done in the district. Surveys by Dings (written communication, 1953) and King and Roseboom (writren communication, 1953) have disclosed three radioactive anomalies. Two of these (the General Teller and the Bell) lie within the favorable zone shown on figure 1; the third (the Jumbo) is north of the indicated favorable zone. These localities are nor shown as anomalies on figure: 1 as none exceeds 0.02 percent eU. Material containing 0.34 percent uranium has recently been reported from the New York mine just southeast of Montezuma.

\section{Argentinedistrict}

\section{Location}

The Argentine mining district is an area about 7 miles long and 3 miles wide, trending northeast, between the Montezuma district on the southwest and the Georgetown-Silver Plume district on the northeast.

$$
\text { Geologic setting }
$$

Most of the district is underlain by Idaho Springs formation and Silver Plume granite. The most abundant Laramide rocks are quartz monzonite porphyry dikes, but rhyolite porphyry, dacite porphyry, and monzonite porphyry dikes are present. Most of the dikes strike not?heast or easí, but a few short ones strike northwest. The veins in the district generally trend north-northeast to east-northeast, but a few strike northwesterly.

$$
\text { Zoning and conclusions }
$$

The Argentine district contains no known pyritic-gold veins and in most of the veins lead-zincsilver ores greatly predominate over other types, Lovering ( 1935, F, 61) noted that sphalerite and pyrite increase with depth in lead-silver veins, but systematic changes in mineralization throughout the district are minor. Lovering (1935, p. 61) suggested a possible center of mineralization between Kelso Mountain and Torreys Peak in the western part of the district, but available data do not indicate any significant lateral zoning. Results of examination for radioactivity of about 25 mines, dumps, and areas of outcrop in the district were negative (King and Roseboom, written communication, 1953). 
Georgetown-Silver Plume district

Location

The Georgetown-Silver Plume district is an area of about 25 square miles in the west-central part of Clear Creek County and fncludes the towns of Georgetown and Silver Plume. The district is bounded by the Argentine district on the south, by the Empire district on the north $\mathrm{b}_{\bullet}$ by the Lawson-Dumont district and the Freeland-Lamartine area on the northeast.

$$
\text { Geologic setting }
$$

The Precambrian complex of the district includes the Idaho Springs formation. Silver Plume granite, quartz monzonite gaeiss and greissic granite. Laramide intrusives include dikes of dacite, quartz monzonite porphyry, granite porphyry, alaskite, and bostonite. The dikes generally strike northwest and are most abundant in the mineralized area around Silver Plume and Georgetown. Some of the less persistent dikes trend east and northeast. Two stocks of monzonite and quartz monzonite occur in the northwest corner of the district.

The faults in the district dip steeply and are classified according to strike into three main systems: (1) $\mathrm{N}_{-} 70^{\circ} \mathrm{E}$. (2) $\mathrm{N}_{0} 70^{\circ} \mathrm{W}$, and (3) N. $50^{\circ} \mathrm{E}$.

$$
\text { Zoning and conclusions }
$$

Spurr. Garrey, and Ball (1908, p. 130) describe a narrow northeast-trending zone of pyritic gold deposits (George town-Saxon Mountain) bordered on the east, south, and west by areas of silver-lead-zinc velns. The evidence presented by them, however, is contradictory; and the transition zone, revealed by a plot of vein types, is indicated on figure 1 only on the southeast side of the area of dominantly gold-bearing veins.

Little reconnaissance for radioactivity has been done in this district, and no anomalies are plotted on the map. Relatively high tadium content has been reported from waters from the Centennial mine _/。

_/ Georgetown Courier, Georgetown, Colo. 1919. 
King (1951, oral communication) states that radioactiviry has been reported in the vicinity of the Colorado Central group and that radioactive water from the Mendo:a mine has beer sampled by the Coilora sio State Board of Health. The Centennial mine is within the transition zone outlined on figule 1 and the Colorado group is close to it. The Mendota mine may lie near or within the possible westward exrension of the zone. There are only two known bostonite dikes in the district, and it may be significant that all three radioactive localities are close to one or the other of the bostonite dikes.

\section{Caribou distict}

Location

The Caribou district is in the west-central part of Boulder County, about 20 miles west of Boulder and about 4 miles north-northwest of Nederland. It lies just west of the western end of the Eoulder County tungsten district and is bordered on the south by the Eldora distric:

\section{Geologic setting}

Boulder Creek granite and schist of the Idaho Springs formation underile most of the easiern half of the district; a large Tertiary composite stock of quartz monzoníte, mpnzonite, gabbro, and related ultrabasic intrusives covers most of the western half of the district. Southeast ard east of the stock is a swarm of east-trending dikes. Many of the dikes have an ourcrop length of more thar haif a mile; they are believed to be younger than the stock.

Most of the veins strike nearly east, but a few trend northwest. The ore minerals are predominantly sulfides, but native silver and gray copper are common.

\section{Zoning and conclusions}

The zonal pattern of the district shows a central area of pyritic gold veins in the vicinity of the St. Louis mine, with a surrounding area containing lead-zinc-silver veins. The zone inferred to be favorable for pitchblende contains predominantly lead-zinc-silver veins peripheral to the central area of pyritic gold veins and includes the uranium deposit at the Carbiou mine (Moore, Cavender, and Kaiser $/$ )。

I Moore. F。 B。. Cavender. W。 W., and Kaiser, E. F., in preparation, Geology and uranium deposits - of the Caribou area. Boulder County, Colorado: U。 S。 Geol. Survey Bull. 
Uranium minerals, other than the pitchblende at the Caribou mine. have not been recognized on other mine dumps or in other accessible workings in the district; no additional significant radioactivity due to uranium has been detected (Moore, oral communication, 1953; King, written communication)。

\section{Ward district}

\section{Location}

The Ward district includes about 20 square miles in the vicinity of Ward and Sunset. The district is bordered on the southeast by the Boulder County tungsten belt and the Gold Hill district.

$$
\text { Geologic setting }
$$

The Idaho Springs formation crops out in a wide arcuate belt, concave to the northwest, in the southern and eastern parts of the district; Silver Plume granite underlies most of the northern part of the district.

Many types of Laramide intrusive rocks occur as both stocks and dikes. Rocks of monzonitic and quartz monzonitic composition predominate but basalt, diabase, diorite, syenire, alkali syenite, alkali monzonite, rhyolite, alaskite and bostonite are also present.

Most of the veins strike west-northwest and dip north. A few veins in the southeast part of the district strike northwest and northeast. Pyritic gold veins containing chaicopyrite and lead-silver veins with minor sphalerite and gray copper account for most of the production of the district; a few veins contain gold tellurides and tungsten.

$$
\text { Zoning and conclusions }
$$

The zonal pattern in the district is complicated by the presence of two pyritic goid centers: one in the vicinity of Ward and the other to the west of Sunset. Although the total number of productive leadsilver veins is relatively small and information on the mineralogy of the veins is scanty the data available indicate a zoning roughly analogous to that at Central City.

With the exception of a single car traverse across the southern part of the district which located a intensity anomaly (not shown on fig. 1) at Copper Rock, no other reconnaissance for radioactivity is known to the writers. 


\section{Jamestown district}

Location

The Jamestown district covers an area of about 36 square miles in the central part of Boulder County and lies north of the Gold Hill district at the northeastern end of the Front Range mineral belt.

$$
\text { Geologic setting }
$$

The Idaho Springs formation, interfingered with Boulder Creek granite, crops out along the southern border of the district and an elongate mass of granite similar to the Boulder Creek granite forms the Overland Mountain stock along the western edge of the district. Silver Plume granite with irregular patches of Idaho Springs formation, Swandyke hornblende gneiss, and pegmatite underlies a large part of the district。

The Precambrian rocks are cat by persistent northwest-trending breccia reefs of Laramide age. The most prominent Tertiary intrusives in the area are two stocks. One, of hornblende granodioite, occupies about 4 square miles in the south-central part of the district, and the other, a sodic granite-quartz monzonite porphyry, covers about 1 square mile on the northeastern border of the larger granodiorite stock. Laramide dikes range in composition from diabase to alaskite and include severai dikes of bostonite porphyry in the east-central part of the district. The dikes generally strike either northwest or northeast。

The veins are of four main types and follow two sets of fractures: an older northwest -trending set generally contains lead-silver and fluorspar deposits. and a younger northeast-irending set contains veins of the pyritic gold and telluride type ores.

$$
\text { Zoning and conclusions }
$$

The deposits of the district in order of decreasing age, are: (1) lead-silyer deposits. (2) fluazspar veins and breccia zones; (3) pyritic gold ores, and (4) telluride veins. A few lead-silver veins and tungstenbearing veins, both apparently late. occur in the southern part of the district, at the outer edge of the telluride zone. The veins in the southern part of the district may be related to the mineralization in the Gold Hill district; unfortunately the mineralogy of most of these veins is unknown. 
Most of the veins of the district are clustered around the stock of sodic granits porphyry and probably are related to it. In the central part of the district a northwesterly-trending fishtook-shaped zone contains the early lead-silver veins and fluorspar ores (fluorite zone); pyiric gold veine occur to the north, east, and south of the fluorite zone; and telluride veins are irregularly distributed around the feriphery of the area containing the fluorite and pyritic gold veins.

Lovering and Goddard (1950. p. 260) attribute the irreguiarity of the zoning ro 3 factors: (1) the sodic granite magma rose from the southwest and the force of its intrusion opened fractures and breccia zones favorable for the migration of ore solutions in the steeply pitching roof southwest of the stock, (2) the iarge granodiorite stock to the south contained fractures suitable for entry of ore fluids only near its borders; and (3) the strong northwesterly breccia reefs served as channels for some of the ore-bearing solutions and thus affected the distribution of the ores.

Except for radioactive pegmatite minerals (Goddard and Glass, 1940), all known anomalies are associated with the fluozite deposits. (King. written communication; Phair, orai communication, 1953,); uraninire (Phair and Onoda, written communication, 1950) and uranothorite (Phair and Shinamoio, 1952) have been identified from the fluorite ore. No abnormal radioactivity is kncwe in the pyritic gold veins or the relluride veins except where they locally contain fluorite. Only one of the early iead-silver veins (Alice) has been checked and no anomalous radioactivity was observed, although scme of the ore contains commercial a mounts of fiuorspar.

The zonal positions and age relations of lead-silver deposits and pyritic gold deposits are reversed in the Jamestown district compared to the Central City district. The zonal pareen of these two types is poorly developed and is complicated by the fluorite and ielluride ores.

Lovering and Goddard (1950, po 261) suggest that the fluorspar deposiss occupied early faults. The affinity of uranium to fluorine apparently was the dominant factor controlling the distribution of uranium in the district. 


\section{Gold Hill distict}

\section{Location}

The Gold Hill district covers about 12 square miles in the central part of Boulder County ${ }^{\circ}$ it is adjacent to the Jamestown district on the north, and the Bowlder County tungsten district on the south and southwest, and lies just to the east of the Ward districr.

$$
\text { Geologic seiting }
$$

Boulder Creek granite. cut by several dikes of Silver Plume granite and pegmatite, underlies nearly all of the district. The Idaho Springs formation crops out along the western and northwestern edges of the district. Laramide dike rocks include diabase, quartz monzonite, alaskite, bostonite. and biotite latite intrusion breccia.

Strong northwest-trending breccia reefs are the dominant Laramide structures. Less persistent breccia reefs trending N. $60^{\circ}-85^{\circ} \mathrm{W}$. break across between reefs of the stronger system. The fissures occupied by the ore deposits are younger than the breccia reefs. Most of them strike $N_{0} 30^{\circ}-60^{\circ}$ E. and dip steeplyi a few strike about $\mathrm{N}, 60^{\circ} \mathrm{W}$, and others strike nearly east。

\section{Zoning and conclusions}

Three main types of veins are present in the district: pyritic gold, lead-zinc-silver, and gold telluride which is most common. Gold telluride veins are distributed throughout the mineralized parts of the district and apparently bear no direct genetic relation to the relatively few pyritic gold veins or to the lead-zinc-silver veins which Goddard (1940) believes may be both earlier and later than the telluride veins.

In April. 1953, Campbell and Schafer (written communication) examined more than 90 localities in the Gold Hill district to determine if there is any correlation between anomalous radioactivity and vein types. Most veins showed abnormal radioactivity ranging from one and one-half to five times background. In July 1954. Wallace and Laub examined more than 300 additional localities throughout the district and sampled and mapped more than half a mile of selected mine workings at a scale of 1 inch to 20 feet $\mathrm{A}$ comparison of uranium content of samples with local geologic setting, mineraiogy, spectrographic analyses. 
assay results, and production data of selected mines, taken from the records of the Boulder Sampling Works. Boulder. Colo, shows no apparent correlation between uranium and vein type, wall rock, other element, or suites of elements.

Data now available indicate that parts of many veins of all types are anomalously radioac?ive. Anomalous radioactivity was also found along numerous small iron-stained fractures. Many of these radioactive fractures cut fresh country rock, and some are as much as 800 feet from the nearest known vein. Ir is concluded that the present distribution of radioactivity in the district may be the result of precipitation of uranium compounds from: (1) hydrothermal solutions in which the uranium was a primary constituent of the solutions; (2) hydrothermal solutions in which the uranium was extracted during migration from uraniferous bostonite, pegmatite, Silver Plume granite, or older veins, and (3) meteoric water that has leached and transporied uranium from any of the pre-existing uranium-bearing vein or rock types.

The writers feel that district zoning cannot be demonstrated within the Gold Hill district and that widespread--though generally low-intensity--anomalous radioactivity shows no definite correlation with vein type.

\section{Eldora district}

Location

The Eldora district includes about 12 square miles in the vicinity of Eldora, at the southwestern end of the Boulder County tungsten district. It is bordered on the north by the Caribou district.

$$
\text { Geologic setting }
$$

The Precambrian complex in the district consists of schists of the Idaho Springs formation with scattered irregular masses and lenses of granite gneiss related to the Boulder Creek granite. Most of the western part of the district is underlain by Tertiary stocks of monzonite porphyry and porphyritic quartz monzonite; east and north of Eldora is a group of eastward-trending Tertiary dikes of hornblende monzonite porphyry and hornblende and biotite andesite. The veins of the district have been worked mainly for gold-sílver tellurides. 


$$
\text { Zoning and conclusions }
$$

Lindgren (1907) noted the occurrence of both telluride veins and sulfide veins in the district and believed that the sulfide veins were later than the telluride veins. No zoning of deposits has been noted in the literature and none is apparent from the data compiled and shown on figure 1 of this report.

Data on radioactivity in the district (King, written communication) show anomalous radioactivity at two -- the Platteville and Shirley mines-- of the approximately 15 properties examined; both of these mines are on telluride veins. A 500-pound sample from the Platteville mine is reported to have contained almost 8.9 pounds of uranium (Sims. H. E. , written communication ).

\section{Magnolia district}

\section{Location}

The Magnolia district is about 5 miles west of Boulder just south of the southeastern edge of the Boulder County tungsten district.

$$
\text { Geologic satting }
$$

The Magnolia district lies entirely within a large body of Boulder Creek granite. The Livingston breccia reef (a Laramide fault) trends about $\mathrm{N}_{0} 25^{\circ} \mathrm{W}$. across the middle of the district and is locally paralleled by a diabase dike of Tertiary age, known as the lron dike.

The ore deposits of the district are chiefly of the gold-telluride type, but some tungsten ore has been mined. Vanadium minerals. chiefly roscoelite, are relatively abundant, and some ore was shipped from the Kekionga vein in 1910 for its vanadium content (Lovering and Goddard, 1950, p. 234). The goldtelluride veins strike generally west or northwest, but most of the tungsten veins trend east or east-northeast (Wilkerson, 1939a, p. 94).

$$
\text { Zoning and conclusions }
$$

There is no recorded occurrence of stiong sulfide mineralization nor do the available data indicate any significant mineral zoning in the district.

To the writers" knowledge, no radioactivity data are available for the Magnolia district. 


\section{Boulder County tungeten distric:}

Location

The Boulder County tungsten district is a ramow west - miles long، extending from about 4 miles wesf of Boulder to the vicinity of Nederland. For most of its length the belt is 1 to 2 miles wide, but near its western end it widens and includes a group of tungstenbearing veins about $11 / 2$ miles southeast of Nederland. The beli is bounded on the northeast by the Gold Hill and Ward districis, on the southeast by the Magnolia district, and on the west by the Caribou and Eldora districks.

$$
\text { Geologic setting }
$$

Most of the district lies within the northwestern part of the Boulder Creek granite batholith. A small, but very productive, part of the district is in an area urderlain by the Idaho Springs formation, which borders the batholith on the west. Monzonite and hornblende monzonite porphyry dikes of Tertiary age are common in the western half of the district; several dikes of biotice latite porphyry and intrusion breccia occur in the eastern part of the district. Laramide structures include nozthwest-trending breccia reefs, and younger east- ard northeast-trending fractures which contain most of the veins.

The dominant ore mineral in most of the veins of the district. is ferberite; wolframite occurs locally and scheelire is a minor constituent of many of the ores. Some tungster veins show evidence of a weak. sarly sulfide mineralization and some contain later sulfides (pyrite, marcasire, galena, and sphalerite) gentically associated with the ferberite. A few telluride veins occur in the eastern part of the district, but these are older than the tungsten veins and may be related to the telluride mineralization of either the Gold Hill districe or the Magnolia district or both.

$$
\text { Zoning and conclusions }
$$

No genetic lateral zoning is recognized in the Boulder County tungsten district and the distribution of vein types is probably the result of the supezposition of the tungsten mineralization of areas containing earlier lead-zinc-silver veins and telluride veins. 
Traces of uranium have been found in ores and vein materiai of the district. Harder and Wyant (wrinten communication) report that jig and table concenzave; from the tungsten mills contain 0.014 to 0.049 percent $e U$, but examination of about 130 mines ard piospects (most locations unknown) and 5 miles of breccia reef outcrop showed radioactivity at only two localiries: tre Pueblo Belle mine, and on the Livingston breccia reef near the Pueblo Belle (King, written communication). Ogden Tweto (oral communication 1954 ) has observed fluorescent secondary uranium minesais coating fractures at several localities in the vicinity of breccia reefs.

The sparse anomalous radioactivity may be related to the breccia zeefs and/or to the tungsten mineralization.

\section{DISCUSSION OF SOME ASPECTS OF URANIUM AND ZONING}

\section{Metal ratios as zone indicators}

The zoning of districts described in this report is based largely on the mineralogy of the deposits. In districts where a geographic mineral zoning pattern is not readily apparent, but where the deposits are thought to be related to a particular intrusive mass or some "source area, a zona"i pattern may possibly be discovered by the use of metal ratios.

In the Wallapai district, Arizona, the deposits seem to be genetically related to the Ithaca Peak granite (Dings, 1951)。 but evidence (based on the mineralogy of the deposits) of lateral zoning around the granite is generally lacking. In an attempt to discover a zonal distribution of deposits, the metal ratios gold/ silver, copper/zinc, zinc/lead, gold/copper, and silver/copper were computed for some of the mines in the district using production figures given by Dings (1951, po 147). These ratios were plorted at the position of their: respective mines, and the resultant zonal pattern for some of the metal atios is shown of figure 2. Also shown are localities containing material with anomalous radioactivity (U. $S_{0}$ Atomic Energy Commission, written communication, 1953). The radioactive deposits appear to be in or near areas where the veins have a high copper/lead ratio and an intermediate gold/silver ratio. Data are inadequate for the other ratios to show definite patterns for the critical area at Wallapai. The correlation berween radioactive deposits and 
certain metal ratios is tentative as data are inadequate in several critical areas. The indicated pattern (fig. 2). however, is crudely analogous to the zonal patiern at Central Ciry. Colo. though at Central City the intermediate zone carrying pitchblende probably has higher copper/lead and gold/silver ratios.

At least one other area in the Wallapai district, centering about 1.5 miles southeast of Chloride in the northern part of the district, shows a similar high copper/lead ratio and an intermediate gold/silver ratio (Leonard, 1952). Although this area was also covered by systematic radsoactivity reconnaissance. no significant anomalous radioactivity was detected, and the area is nor shown on figure 2.

\section{Mineral associations}

\section{Chalcopyrite}

Evidence from several Front Range districts suggests that copper in the form of chalcopyrite is most abundant in the transition zone. Chalcopyrite is common in many of the veins of the Central City district, but it is an economically important ore mineral in only a few of them. Incomplete data from the Mineral Resources of the United States and from unpublished records of the $U_{*} S_{*}$ Bureau of Mines show that copper produced from chalcopyrite (with minor gray copper) in the Central City district has come

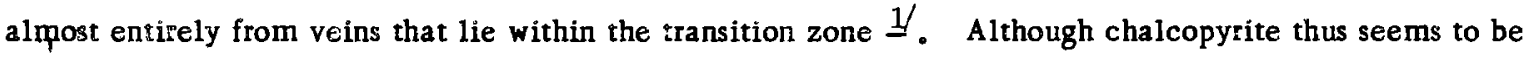

\footnotetext{
1 Copper has also been produced from the enargite-bearing veins of the core zone.
}

more abundant in the rransition zone, it is not restricted to any one vaia type. The same is true of pitchblende and the data available for the Central City district indicate only a general association of chalcopyrite and pirchblende (within the transition zonit) and not a specific one (in the same veins).

In the Freeland-Lamartine and adjacent areas, however, there is some evidence suggesting that the association of chalcopyrite and pitchblende tends to be restrictive. Wells and Harrison (1954) sampled mine dumps and workings in an area of about 30 square miles in the north central part of Clear Creek County and report that: (1) only a small percentage of veins showed significant abnormal radioactivity at 
localities where pyrite was the sole metallic mirezal identified; $(2)$ the greategt' percentage of veins showed significant ab̉normal radioactivity at localicies where chalcopyzite and pyrite were identified, and: (3) significant abnormal radioactivity was found at nearly the same percentage of localities where chalcopyrite and pyrite were identified as those where galena, sphalerite, and chalcopyrite were identified. They . conclude that if the presence of chalcopyrite defines the intermediate zone berween pyritic veins and galenasphalerite veins, the intermediate zone appears to be :he most favorable area for prospecting for pitchblende in this part of the Front Range.

At least one other district apparently shows a general relation between chalcopyrite and pitchblende. This is Comwall, England, a classic district for mineral zoning, where pitchblende is most common in the copper zone (Davidson, C. F。, 1952, oral communication)。

\section{Other minerals}

In the Jamestown district uranium is definitely associated with fluorspar. This rassociation of uranium wigh fluorite has been noted in many districts: Thomas Range. Utah--fluorite with carbonate gangue; Marysvale, Utah--fiuorite with minor pyrite, magnerite, and secondary sulfates and oxides; Wolsendorf. Bavaria, fluorite with barite, quartz and carbonate gangue, and specularite, pyrite, chalcopyrite, and galena; and others. In contrast there are many fluorspar deposits that contain po appreciable uranium and many uranium deposits are in districts that are essentially lacking in fluorite. Essentially these same general relations hold for the association of uranium with cobalt and nickel sulfides, arsenides, etc.. and silver minerals.

\section{Conclusions}

Certain characteristic minerai associarions may be valid, although not completely restrictive * within a district. Either one or the other of any "mineral pair" may be absent or present only in trace amounts. The association of uranium with certain other minerals may be a useful prospecting guide--either from a zonal viewpoint or on the basis of individual deposits. The concept must be applied with caution and is most useful where the validity and degree of association are known within any one district. 


\section{Pitchblende in the paragenetic sequence}

Within the Front Range mineral belt, the paragenetic relation of pitchblende to sulfides is known only from the Quartz Hill area of the Central City dis rict, from the Carbou district, ard from one locality in the Gold Hill dïstrict. A single specimen of hard pitchblende from an adit jusr east of the Silver Queen shaft (?) in the Gold Hill district is cut by fine stringeri of horn quartz concaining pyrite. At the Caribou mine in the Caribou district pyrite, sphalerite and galena are both younger and older than pitchblende (Wright, written communication, 1950). In the Central City district many specimens show brecciated pitchblende cut and cemented by pyrite and chalcopyrire which are older than galena and sphalerite. P. K. Sims foral communication, 1953), states that in some specimens the pitchblende appears to be contemporaneous with pyrite, and Bastin and Hill (1917, p. 123-124) believed that pitchblende was contemporaneous with some chalcopyrite. A single specimen owned by $R_{0} R_{0}$ Hinckley of Russel Gulch, Colo, taken from the West Calhoun mine, contains galena coated with pitchblende which in turn is overgrown in places by marcasite (P. K. Sims, oral communication, 1954).

Although the age of pitchblende relative to sulfides is quite varied, most of it appears to be older than most of the sulfides, including the pyritic gold ores which predominate in the core zone. According to the classic concept of hypogene zoning as presented by Emmons: (1926) the predominamt minerals in any zone should be older than the predominant minerals in any zone further from the source. Thus, pitchblende in the Central City district should be younger, and not older than the pyritic gold ores as indicated by the paragenesis. There are at least two possible explanations of this discrepancy. Lovering and Goddard (1950. p. 84) note that a zonal distribution of metals is common around many local centers of mineralization and that in many places there is some overlapping of zones from adjacent centers. Unless the rather unlikely assumption of exactly simultaneous mineralization from separate centers is made, it is possible therefore that within a zone of overlap. late minerals from the first-mineralizing source will appear as early minerals relative to those deposited from the source which was active later. A second possible explanation of the apparent contradictory age-position relationship is deposition at any give point in an environment of changing physical-chemical conditions; that is, a zone with an environment of deposirion favorable for the precipitation of one suite of minerals may encroach upon zones in which the environmeni of deposition and resuliant 
mineral suite were originally quite different. Thus, with "increasing intensity" conditions, minerals which during earlier stages of mineralization deposited main:y in the central zone of a district may be deposited in the next outer zone, and cut, vein, and replace minerals that in the early stages of mineralization were younger than the minerals of the core zone.

In addition, certain unrecognized physical-chemical controls of deposition and solution, similar to those that may account for the common "reversal " of sphalerite and chalcopyrite in the zonal-parageneric relation, may have operated.

For the reasons stated above the writers do not believe that an early age of pitchblende relative to the pyritic gold ores in the Central City district necessarily invalidares a genetic relation of pitchblende to the zonal sequence.

\section{Fault patterns}

Vein formation is dependent upon the presence of pre-mineral openings and the deposition of minerals, either by, replacement or open filling or both, from solutions passing trhough the openings. The vein pattern is thus influenced both by the distribution of pre-existing fractures and the accessibility of the fractures to mineralizing solutions. The distribution o: pre-vein fractures is influenced by the distribution of rocks of varying physical properties, and by the type. intensity and localization of stresses on the rocks. An example of the effect of country rock on fractures is found in the Central City district where open fissures formed less readily in the Idaho Springs formation than in other rock types, and the distribution of rock types has thus influenced the distribution of fractures. The importance of the type of stress producing the fractures is the fracture pattern that surrounds and is related to the shape and mode of intrusion of a stock of soda granite in the Jamestown district (Goddard, 1935). At Gold Fill Goddard (1940) suggested the impprtancf of the breccia reefs in serving either as main distributaries to the vein fissures, or as dams blocking the flow of ore solutions. The Dory Hill fault is thought (Lovering and Goddard, 1950) to have localized the belt of telluride mineralization in the Central City district.

The configuration of zones shown by variations in the mineralogy of the veins in a district is, of necessity, restricted by the total vein pattern. Within this pattern, the distribution of different vein types is 
influenced. not only by the distance of the vein from the source of the solutions, but by the accessibility of different groups of fractures at different times to ore solutions of changing composition. The control of fault patterns on zoning, either direci or indirect, is thus very great, even in the simple case where all the veins in a district are the result of one period of mineralization from a single source.

$\mathbb{I}_{n_{k}^{2}}$ the Freeland-Lamartine area, Harrison (1953) noted a linear zoning along veins in cymoid fractures, with pyritic gold ores in the central segment, and slightly younger lead-zinc ores in the laterformed terminal segments. He believes (oral communication, 1954) that a similar linear zoning may also be applied on a much larger scale to vein systems. If this concept is correct, the concentric pattern at Central City might be explained by the overlapping of roughly linear zoning along two or more systems of cymoid fractures.(See fig. 3.)

\section{Vertical zoning}

Changes in mineralogy and tenor of ore with depth in individual veins or groups of veins have been noted at various places in the Front Range mineral belt. As mentioned previously, there is some suggestion that the interface between the zone of pyritic gold veins and the zone of lead-zinc-silver veins in the north" ern part of the Montezuma district may be relatively flat. The writers believe that the boundary surfaces between zones in many of the districts may be generally steeper but are probably quite irregular. Unfortunately. the shape, slope, and thickness of favorable zones, and therefore their location with depth, are generally unknown in the Front Range districts.

\section{Relation of uranium to radioactive Teriary porphyries}

A spatial relation between bostonite dikes and pitchblende deposits has long been recognized in the Censeal City district, and a genetic relationship between them has been suggested by several workers.

The bostonite of the Front Range (Spurr, Garrey and Ball, 1908; Fhair, 1952; and Wells, oral communication. 1954) is lime- and magnesia-poor with dominant alkali feldspar and a fine-grained trachytoid texrure, with or without phenocrysts of potash feldspar, and with varying amounts of sillica. Accessory minerals in different specimens include aegirine-augite, sphene. apatïte, andradite, quartz, fluorite, 


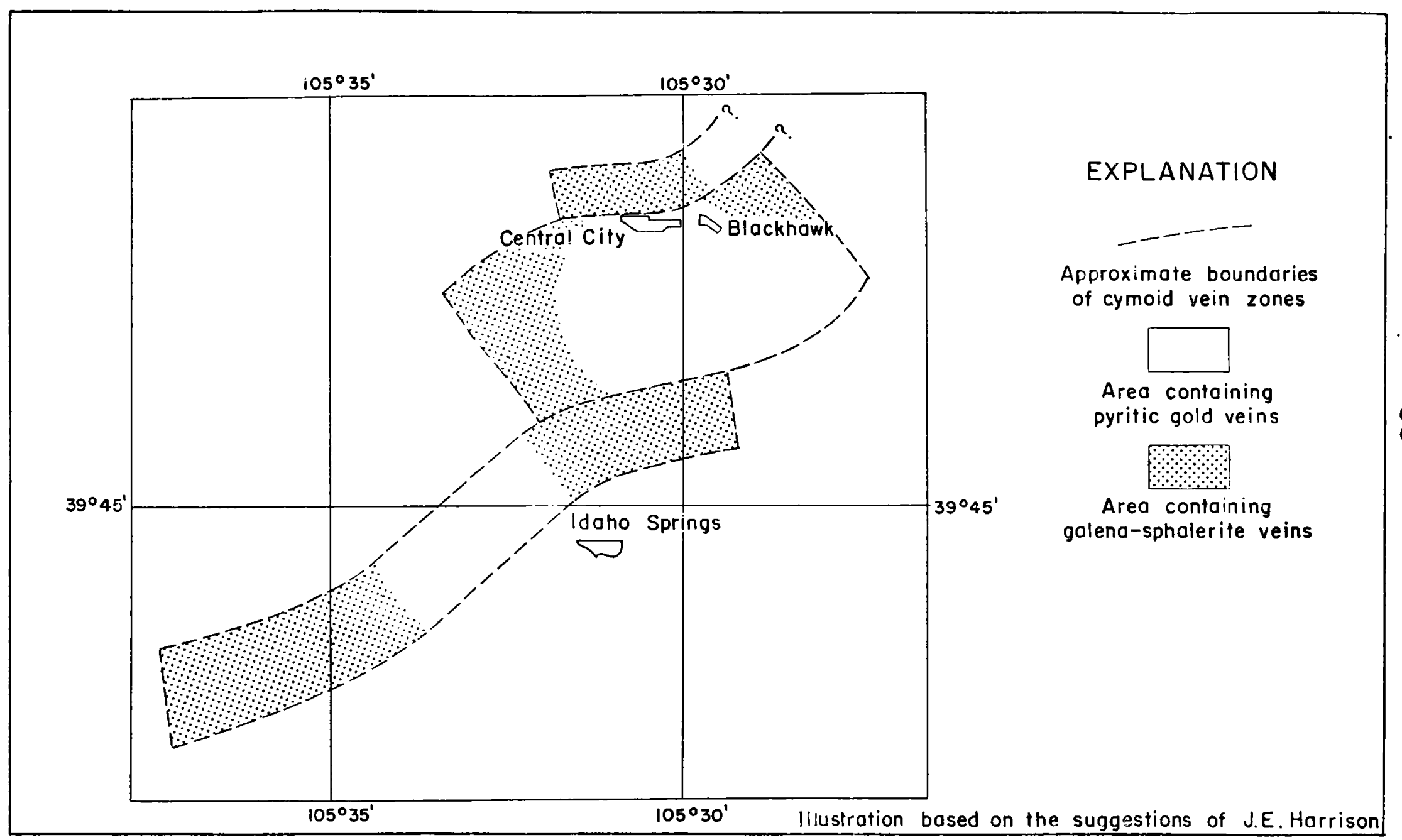

FIGURE 3.-DIAGRAMMATIC SKETCH SHOWING HOW A ROUGHLY CONCENTRIC ZONAL PATTERN MAY BE DEVELOPED AS A RESULT OF ADJACENT, EN ECHELON CYMOID VEIN ZONES.

$\begin{array}{rrrr}0 & 1 & 2 & 3 \text { Miles } \\ 1 & 1 & 1 & 1\end{array}$


and zircon. In the Central City-Idaho Springs district, these rocks occur mainly as dikes; some of these are persistent and one has been traced for about $41 / 2$ miles. Lenticular masses as much as one-eighth mile wide occur both as isolated bodies and as local swellings along dikes.

Both bostonite and pitchblende are more abundant in the Central City-Idaho Springs district than in other parts of the Front Range mineral belt. Aisdorf (1916) noted a spatial relationship of bostonite and pitchblende deposirs in the Central City district. He further observed that pares of some bostonite dikes in the district are strongly radioactive and suggested a genetic relationship between bostonite and pitchblende. Phair (1952) subdivided the bostonites as syenitic bostonites, non-porphyritic quartz bostonires, and quartz bostonite porphyries and found that all three types are abnormally radioactive. The non-porphyritic quartz bostonites are the most radioactive and contain as much as 20 times the uranium content of the "average granite."

Phair (1952) has shown a rough correlation between radioactivity and zircon content of the quartzbearing bostonites. The affinity of zirconium and uranium is also expressed in the composition of the uran:nite which Phair believes was deposited from solutions derived from a bostonite magma. Hillebrand (1888, 1890, and 1891) analyzed a uraninite specimen from Elack Hawk (Central Ciry district) which contained 7.59 percent $\mathrm{ZrO}_{2}$. Phair (oral communication, 1954) found approximately 5 percent $\mathrm{ZrO}_{2}$ in uraninite from the Wood mine. These values compare with a zirconia content of ¡generally less than one percent for analyzed uraninite specimens from districts in many other parts of the world.

The geographic and geochemical relationships nored above suggest a genetic tie between bostonite and pitchblende in the Central City district The writers, however, feel that the geographic relation of pitchblende and the bostonites is general (within the district) and not specific as suggested by Asldorf 1916 ) and Phair (1952).

The Central City district is the type area for the concept of a relation of uranium to mineral zoning. If bostonite and uranium are related and if pirchblende is related to the sulfides, then there should be a genetic relation between bostonite magma and the sulfide mineralization of the district. There is no general agreement on this subject, but the writers believe that the bostonite magma is just as jikely a source 
for the solutions which produced the sulfide mineralization of the district as any of the other Tertiary magmas of the district: Lovering and Goddard (1950, p. 2, 91) consicier bostonites as the source of the solurions that deposited pyritic gold ores. Thus, a relation of bostonite and pitchblende may not necessarily negate the zonal hypothesis of uranium presented in this report; that is, both pitchbiende and the sulfide ores may be related to the bostorites.

In places gabbro, granodiorite, monzonite, biotite larite, and alkali syenite are known to contain appreciably more (4 4 to 8 times) equivalent uranium than that normally found in rocks of corresponding composition ( Phair. oral communication, 1954)。 Although bostonite magmas in the Front Range mineral belt probably contained unusual concentrations of uranium, the scarcity or absence of known bostonites in many districts in which uranium is found and the abnormal uranium content of many other Tertiary intrusive rock types, suggest that uranium-bearing solutions were derived from source magmas other than bostonite.

\section{CONCLUSION}

The writers originally set out to test the hypothesis of a relation between hypogene zoning and uranium. The districts of the Front Range mineral belt have been emphasized because of the relatively large amount of data available. Certainly, there are numerous other mining districts that are zoned and some of these may contain uranium. Many such districts have been considered diring the course of the present investigation, but for most of the districts outside of the Front Ragge mineral belt the writezs have insufficient data to warrant inclusion in this report.

A plot of the Tertiary porphyries of the Front Range mineral belt reveals a complex partern that the writers feel partly reflects complex resevoir condirions during the general period of igneous activity. The writers believe that crystallizing magmas were the source of mineralizing solutions that formed the Tertiary vein deposits in :the Front Range mineral belt; that these solutions were expelled at different times from many separate magma chambers containing magmas of various compositions; that pirchblende is found intimately mixed with other ore minerals in various paragenetic relationships in many veins; that bostonite magmas may have contained relatively large concentrations of uranium, but that uranium-bearing ore solutions were probably derived from many other types of magma; that in many of the districts uranium and other metals were probably derived from the same source; and that in zoned districts containing uranium, the uranium tended to be precipitated in certain zones. 
It seems probable that in some piaces either hydrothermal or meteoric solutions, or both have extracted uranium from uranium-bearing bostonites, pegmarites. Silver Plume granite or veins. Thus, the distribution of uraniferous rocks or veins subject to hydrothermal or supergene leaching has probably influenced to some extent the distribution of radioactívity.

The writers believe that the results of their investigations in the Front Range districts sugges $\hat{\imath}$ that the concept of a zonal relacion of uranium so other metals is a valid one. It is hoped thar this report will encourage other workers in geology to test further the concept of a preferred position of uranium in zoned $r$ metalliferous districts, and that the zonal hypothesis will prove useful in the search for uranium deposits.

\section{LITERAT URE CITED}

Alsdorf. $P_{0} R_{0}, 1916$, Occurrence, geology and economic value of the pitchblende deposits of Gilpin County. Colorado: Econ. Geology, v。 11。 p. 266-275.

Bastin, E。 S, and Hill, J. M. , 1917, Economic geology of Gilpin County and adjacent parts of Clear Creek and Boulder Counties, Colorado: $U_{0} S_{0}$ Geol. Survey Prof. Paper 94.

Collins, George E. 1903, The relative distribution of gold and silver values in the ores of Gilpin County。 Colorado: Inst, Mining and Metallurgy Trans.o vo XII. p. 480-499.

Dings, M。 G., 1951, The Wallapai mining district, Cerbat Mountains, Mohave County, Arizona: U。 Geol. Survey Bull.978E。 P. 123-162.

Emmons, W. H. . 1926, Relations of metalliferous lode systems to igneous intrusives: Am. Inst. Min。 Met, Eng. Trans., vo 74, po 29-70。

Goddard, E. N.. 1935, The influence of Tertiary intrusive structural features on mineral deposits at James-town, Colorado: Econ. Geology, v。 30, no, 4, po 370-385.

1940. Preliminary report on the Gold Hill mining district, Boulder County, Colorado:

Colora do Sci. Soc. Froc. v. 14, no. 4, po 103-139.

1946, Fluorspar deposits of the Jamestown district, Boulder County, Colorado: Colorado Sci. Soc. Proc, $v_{0}$ 15, no, 1 .

- 1947. The Front Range mineral belt in Mineral resources of Colorado: po 294-327, Denver Colorado Mineral Resources Board。

Goddard, E. N . and Glass, Jo J. , 1940, Deposits of radioactive cerite near Jamestown, Colorado: Am. Mineralogist, vo 25, p. 381-404。

Harrison, J. E. . 1953, Relation between fracture pattern and hypogene zoning in the Freeland-Lamartine district, Clear Creek County, Colorado (abs。): Geol。 Soc , America Bull, v. 64, no, $12, \mathrm{pt}_{\circ} 2$, p。1431。 
Harrison. J. E. a and Leonard $B_{0} F_{0}, 1952$. Preíiminary report on the Jo Reynolds area, Lawson-Dumont district, Clear Creek County, Colorado: U. S. Geol。 Survey Circ。213.

Hillebrand, W. F., 1888, Uraninite: Am。 Jour. Scì., 3d。 ser。, v。 36, no, 215, p. 295。

-1890. Occurrence of nitrogen in uraninite and composition of uraninite in general: Am. Jour. Sci. $3 d$ ser, $_{0}$ v. 40, no, 239, p。 384-394。

_1891, New analyses of uraninite: Am. Jour, Sci.。3d ser., v。 42, no. 251, po 390-393.

King, $R_{0} U_{0}$. Leonard,$B_{0} F_{0}$, Moore, $F_{0} B_{0}$, and Pterson, $C_{0} T_{0}, 1953$, Uranium in the metal-mining districts of Colorado: $U_{。} S_{\circ}$ Geol。 Survey Circ。215.

Leonard, $B_{0} F_{0}, 1952$, Relation of pirchblende deposits to hypogene zoning in the Front Range mineral belt, Colorado (abp, ): Geol. Soc, America Bull., v。63, no, 12, pt. 2. p. 1274-1275.

Lindgren. Waldemar, 1907. Some gold and tungsten deposits of Boulder County, Colo, Econ, Geology. v. 2. P. 457-460。

Lovering, $T, S_{\circ}, 1932$, Relations of ore deposits to geologic structure in Boulder County. Colorado: Colorado Sci. Soc. Proc.. vo 13, no. 3, p. 77-88。

- 1934, Geology and ore deposits of the Breckenridge mining district, Colorado: U. S. Geol. Survey Prof. Paper 176.

1935, Geology and ore deposits of the Montezuma quadrangle, Colorado: U. S。 Geol. Survey Prof. Paper 178.

- 1941. The origin of the tungsten ores of Boulder County, Colorado: Econ. Geology, v. 36. no. 3, p. 229-279.

Lovering, $T_{0} S_{0}$, and Goddard, $E_{0} N_{0}, 1950$, Geology and ore deposits of the Front Range, Colorado: $U_{0} S$. Geól. Survey Prof. Paper 223.

Lovering. T. S.. and Tweto, Ogden, 1953, Geology and ore deposits of the Boulder County tungsten district, Colorado: U. S. Geol. Survey Prof, Paper 245.

Phair, George, 1952, Radioactive Tertiary porphyries in the Central City district, Colorado, and their bearing upon pitchblende deposition: $U_{0} S_{0}$ Geol. Survey TEI-247, issued by $U_{0} S_{0}$ Atomic Energy Comm。Tech。Inf. Service. Oak Ridge, Tenn.

Phair, George and Shimanoto, Ko O . 1952. Hydrothermal uranothorite in fluorite breccias from the Blue Jay mine, Jamestown. Boulder County, Colorado: Am。 Mineralogist, v. 37, po 659-666.

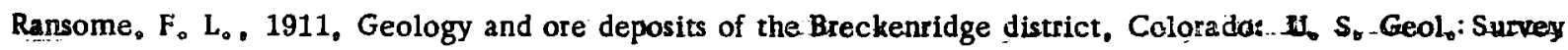
Prof. Paper 75.

Spurr, J. E. Garrey, G。 $H_{0}$, and Ball, $S_{0} H_{0}, 1908$, Economic geology of the Georgetown quadrangle:

U. S。 Geol. Survey Prof. Paper 63.

Tweto, Ogden, 1947, Scheelite in the Boulder district, Colorado: Econ. Geology, v. 42, no. 1, po 47-56. 
Wells, $J_{\circ} D_{0}$, and Harrison $J_{0} E_{0}, 1954$, Radioactivity reconnaissance of part of north-central Clear Creek County, Colorado: U. S. Geol survey Circ. 345.

Wilkerson, $A_{\circ} S_{0}, 1939 a_{,}$Geology and ore deposits of the Magnolia mining district and adjacent area, Boulder County, Colorado: Colorado Sci. Soc, Proc , v。 14, no. 3 。

, 1939b, Telluride-tungsten mineralization of the Magnolia miring district, Colorado: Econ。 Geology。 v。 34, no. 4, p。 437-450.

Worcester, $P_{\circ} G_{0}, 1921$, The geology of the Ward region, Boulder County。 Colorado: Colorado Geol。 Survey Bull。21。 


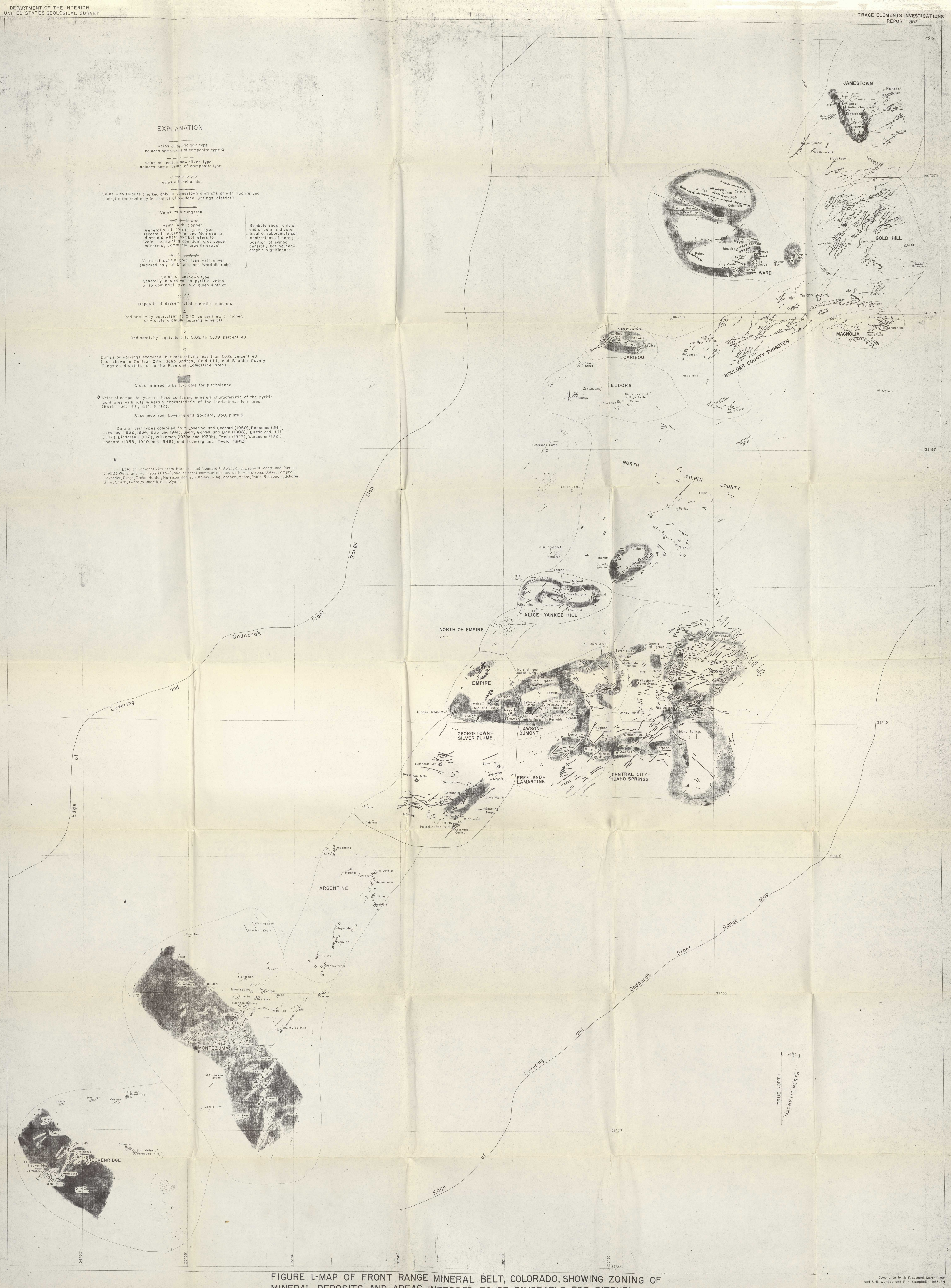





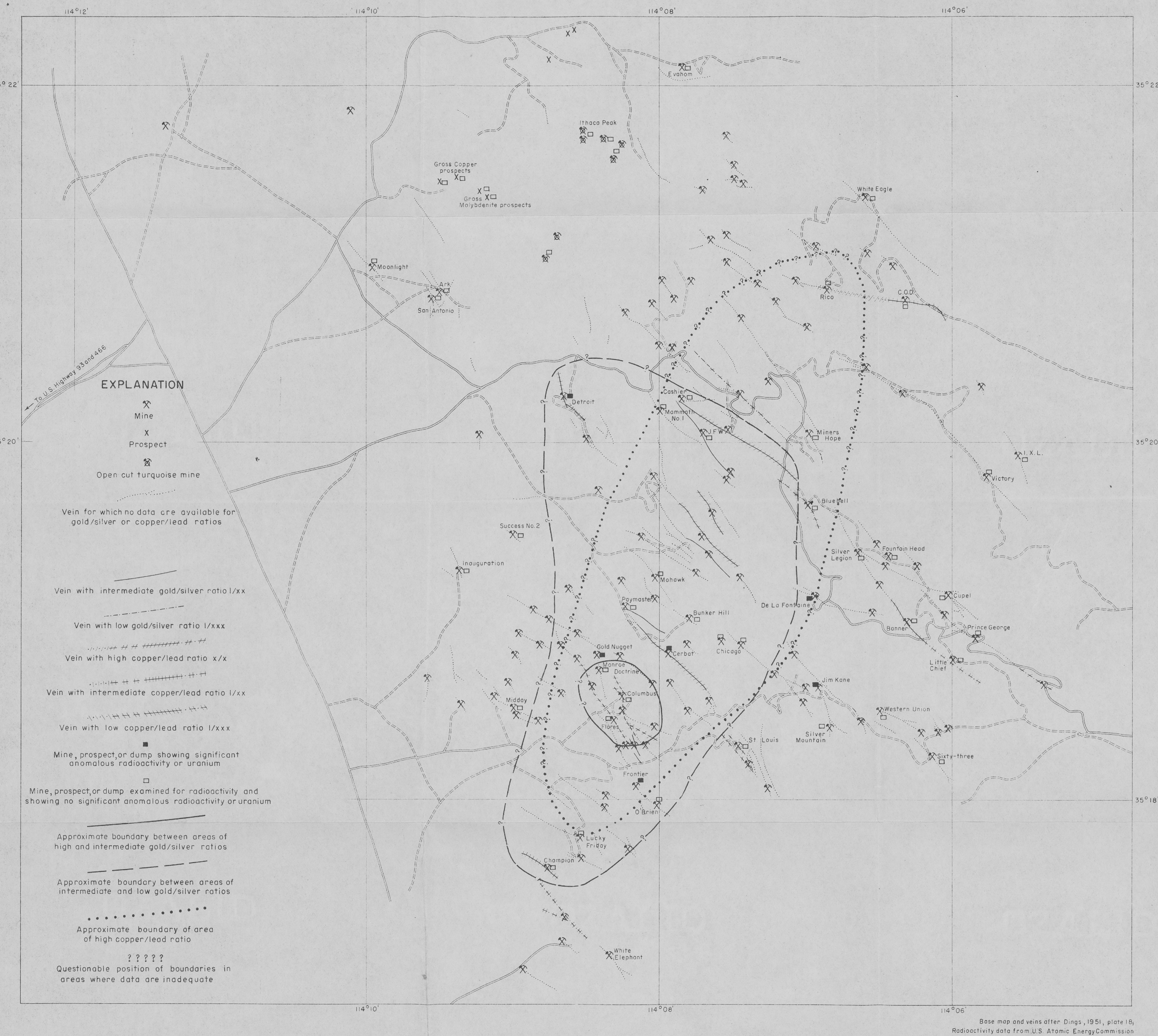

FIGURE 2. - MAP SHOWING ZONAL DISTRIBUTION OF METAL RATIOS AND RESULTS OF RADIOACTIVITY RECONNAISSANCE IN THE SOUTHERN PART OF THE WALLAPAI MINING DISTRICT, MOHAVE COUNTY, ARIZONA 


